\title{
$\stackrel{\circ}{\mathcal{C}}$ \\ Jurnal Civics: Media Kajian Kewarganegaraan \\ https://journal.uny.ac.id/index.php/civics/index \\ 1829-5789 (print) \\ 2541-1918 (online)
}

\section{Pengaruh model kooperatif tipe Think Pair Share terhadap kerja sama siswa}

\author{
Khikmah Fitriani Nurazizah a, 1*, Wuri Wuryandari ${ }^{\text {b, } 2}$ \\ a b Universitas Negeri Yogyakarta, Program Pendidikan Dasar S2, Yogyakarta, Indonesia \\ ${ }^{1}$ khikmahfitriani@gmail.com; ${ }^{2}$ wuri_wuryandani@uny.ac.id
}

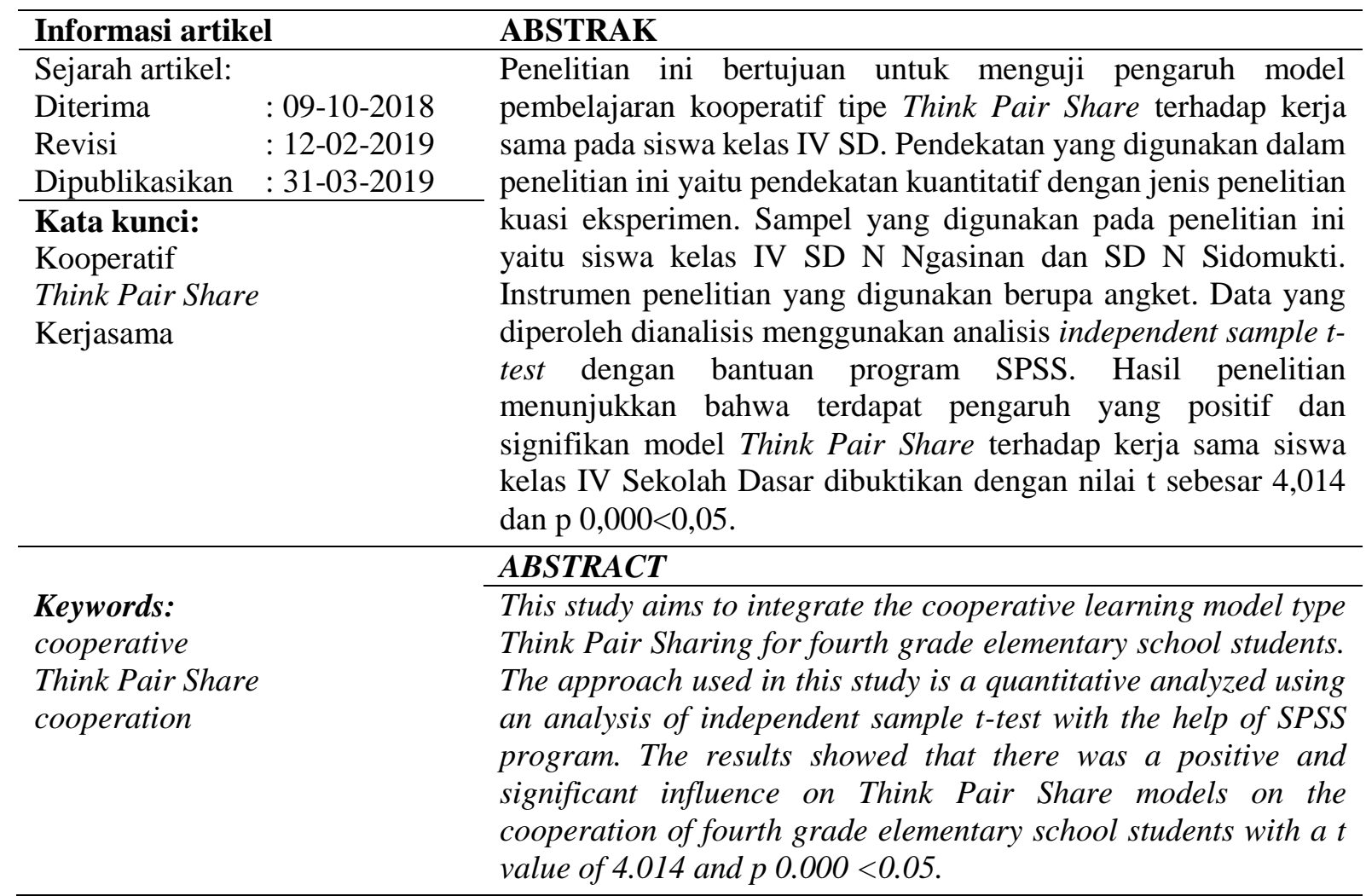

Copyright (C) 2019 Khikmah Fitriani Nurazizah dan Wuri Wuryandari

\section{Pendahuluan}

Pendidikan merupakan aspek yang sangat berpengaruh dalam perkembangan individu. Melalui pendidikan, individu memperoleh pengalaman-pengalaman yang dapat mengembangkan potensi yang berguna bagi dirinya sendiri maupun masyarakat. Pengalaman dapat diperoleh melalui pembelajaran. Pembelajaran merupakan interaksi yang dilakukan pendidik dengan peserta didik pada suatu lingkungan belajar. Lingkungan belajar didukung dengan berbagai komponen pembelajaran. Komponen-komponen tersebut meliputi tujuan pembelajaran, materi, model pembelajaran, pendidik, peserta didik, media pembelajaran, penilaian dan evaluasi. Setiap komponen harus saling mendukung agar tercapai pembelajaran yang berkualitas. Jika salah satu komponen pembelajaran saja tidak dapat terpenuhi maka pembelajaran tidak berjalan dengan baik.

Salah satu komponen dalam pembelajaran adalah tujuan dari pembelajaran itu sendiri. Tujuan pembelajaran tidak hanya diarahkan pada aspek kognitif saja. Siswa juga seharusnya mampu mengembangkan aspek psikomotor dan afektifnya. Dengan demikian, siswa tidak hanya pandai secara kognitif saja tetapi siswa memiliki keterampilan dan sikap yang baik. 
Kurikulum 2013 yang berlaku saat ini, tujuan pembelajaran berfokus pada ranah kognitif, afektif, dan psikomotor. Kurikulum 2013 yang berlaku saat ini menuntut siswa untuk mengembangkan sikap, keterampilan, dan pengetahuan secara seimbang. Kurikulum 2013 tidak lagi mempelajari mata pelajaran secara terpisah-pisah namun mata pelajaran diintegrasikan dalam satu kesatuan yang dikaitkan dengan tema. Pada kurikulum 2013, setiap kelas memiliki tema yang berbedabeda. Kelas IV SD terdapat sembilan tema yang harus dipelajari dalam dua semester. Setiap tema terdiri dari beberapa sub tema yang mengintegrasikan mata pelajaran yang berbeda-beda. Sub tema keunikan daerah tempat tinggalku pada tema daerah tempat tinggalku merupakan salah satu sub tema yang dipelajari di kelas IV SD pada semester dua, pada sub tema tersebut terdiri dari mata pelajaran Bahasa Indonesia, PPKn, SBdP, IPA, dan IPS yang saling berkaitan. Pembelajaran berbasis tema memberikan keuntungan pada siswa yaitu memberikan pengalaman nyata kepada siswa karena tema yang disajikan berhubungan dengan kehidupan sehari-hari siswa sehingga pembelajaran lebih bermakna. Selain itu, psikomotor dan afektif siswa juga dikembangkan sesuai dengan tema masingmasing. Siswa tidak hanya menerima penjelasan dari guru namun siswa dituntut untuk aktif menggali pengetahuan sendiri dari berbagai hal. Selain itu, siswa juga dituntut untuk mampu bekerja secara kelompok. Penggunaan model pembelajaran yang inovatif dan variatif yang dikemas sedemikian rupa akan membantu dalam mewujudkan kemajuan proses dan hasil belajar siswa baik dari aspek afektif, kognitif maupun psikomotor.

Kerja sama setiap siswa dalam mengikuti pembelajaran adalah salah satu faktor penentu keberhasilan belajar siswa itu sendiri. Dalam kurikulum 2013 kemampuan kerjasama sangat diperlukan karena dalam pembelajaran tematik integratif pada menganut pendekatan scientific yang mana siswa diminta untuk berkelompok dalam menyelesaikan permasalahan bersama. Bekerja sama berarti mampu menyelesaikan suatu hal dengan orang lain untuk mencapai tujuan bersama. Kerja sama sangat penting untuk dimiliki oleh setiap siswa, melalui kerja sama mereka dapat mengembangkan kemampuan komunikasi, menghargai perbedaan, kepedulian, dan pencapaian tujuan kelompok.

Pada kenyataannya, pembelajaran yang dilakukan saat masih banyak yang berorientasi pada aspek kognitif saja karena anggapan siswa yang berhasil adalah siswa yang memiliki nilai bagus baik di rapor maupun ijazahnya. Pendidik kurang menyadari bahwa keterampilan dan sikap siswa perlu dikembangkan agar mereka dapat membaur dengan masyarakat luas.

Permasalahan diatas sesuai dengan observasi yang telah dilakukan menunjukkan bahwa siswa kelas IV SD segugus Amarta Kecamatan Bener Kabupaten Purworejo menunjukkan sikap belum mampu bekerja sama dalam kelompok. Hal tersebut dapat dilihat saat kegiatan berkelompok tidak semua siswa berpartisipasi dalam menyelesaikan tugas kelompoknya. Beberapa siswa terus bekerja selama berkelompok, namun ada beberapa siswa yang malah bermain sendiri. Dalam berkelompok siswa cenderung mengandalkan siswa yang paling pintar di kelompoknya ketika mengerjakan tugas dari guru. Setelah melakukan wawancara dengan guru, memang dalam berkelompok anak-anak cenderung seperti itu. Hal tersebut mengindikasikan kurangnya kerja sama siswa dalam menyelesaikan tugas kelompok. Kerja kelompok yang seharusnya menjadi cara belajar bekerja sama menjadi tidak efektif. Selain itu guru belum terlihat melakukan inovasi terkait diskusi kelompok seperti menggunakan model yang bervariasi.

Kerja sama memiliki peranan penting dalam kehidupan. Pada era sekarang ini salah satu kemampuan yang sangat penting adalah kerja sama sehingga siswa dapat mengembangkan kemampuan komunikasi, menghargai perbedaan, kepedulian, dan pencapaian tujuan kelompok (Altun, 2015). Hasil penelitian Frykedal \& Chiriac (2018) pun menunjukkan partisipasi siswa dalam diskusi mendorong proses inklusif dan 
kolaborasi mereka. Dengan demikian, dapat diartikan kerja sama dapat ditingkatkan melalui diskusi. Setiap orang membutuhkan kerja sama dengan orang lain untuk mencapai kesuksesan bersama. Sejalan dengan Lee (2008) yang menjelaskan kerjasama merupakan kebutuhan yang sangat penting. Sikap kerja sama penting untuk dimiliki oleh siswa sekolah dasar. Kerja sama menunjukkan saling ketergantungan bersama untuk mencapai tujuan. Sejalan dengan pendapat Brinkerhoff, Ortega, \& Weitz (2013, hal. 102) yang mendefinisikan kerja sama sebagai "cooperation occur when people work together to achieve shared goals".

Sikap kerja sama yang dimiliki seseorang akan menumbuhkan sikap positif lainnya. Sikap saling ketergantungan menghasilkan sikap yang paling positif dalam kerja sama. Bahkan dengan tujuan kesuksesan, saling ketergantungan menciptakan sikap positif terhadap kerja sama (Bertucci, Johnson, Johnson, \& Conte, 2016). Bekerja dengan siswa lain dapat membantu siswa dalam mengembangkan kemampuan empati mereka dengan memberikan kesempatan untuk melihat sudut pandang orang lain, yang pada gilirannya dapat membantu menyadari bahwa setiap orang memiliki kelebihan dan kekurangan (Muijs \& Reynolds, 2008). Gächter, Herrmann, \& Thöni (2010) menjelaskan banyak masalah sosial yang terjadi yang melibatkan kerja sama yang mana kepentingan bersama mengedepankan kepentingan individu.

Kerja sama dapat memberikan keuntungan yang dapat memaksimalkan dalam mencapai prestasi dan mengembangkan karakter siswa. Siswa memiliki kesempatan yang adil dalam berkontribusi dan saling peduli terhadap belajar dari anggota kelompok (Lickona, 2009). Saat siswa bekerja sama, mereka mendapatkan pengalaman yang dapat mendorong sejumlah keterampilan sosial seperti, menyimak dengan penuh perhatian, membaca petunjuk-petunjuk nonverbal, menyelesaikan ketidaksepahaman (secara diplomatis), mencurahkan sudut pandang orang lain, membuat pernyataan mendukung, dan memberikan pujian tulus (Enggen \& Kauchak, 2012).

Bekerja sama dengan orang lain akan membuka mata kita terhadap kemampuan yang kita miliki. Adanya orang lain yang juga memiliki wawasan pada bidang yang sama akan mempermudah untuk mengetahui tingkat pemahaman yang kita miliki pada suatu bidang. Dengan demikian akan menjadikan seseorang memiliki sikap positif. Kerja sama dapat menjembatani siswa untuk mengembangkan bakat yang dimilikinya tanpa rasa tidak percaya diri. Selain itu mereka dapat mengetahui kelebihan dan kekurangan yang ada pada dirinya sehingga akan tercipta perilaku saling membantu dengan ikhlas dan juga menghormati anggota yang lain.

Dapat kita ketahui bersama bahwa kerja sama dapat mengembangkan kemampuan komunikasi, menghargai perbedaan, kepedulian, dan pencapaian tujuan kelompok. Bekerja sama berarti melatih komunikasi utamanya komunikasi dengan anggota kelompok untuk mencapai kesepakatan bersama. Ketercapaian tujuan bersama akan terwujud jika dalam bekerja sama memiliki sikap saling menghargai dan adanya kepedulian dengan sesama anggota kelompok. Terciptanya kerja sama dalam pembelajaran akan meningkatkan kualitas pembelajaran sehingga tujuan pembelajaran dapat dicapai secara optimal.

Keberhasilan penanaman sikap pada siswa dipengaruhi oleh model pembelajaran yang diterapkan. Penggunaan model pembelajaran yang inovatif dan variatif akan mempermudah dalam mengembangkan sikap siswa. Salah satu model pembelajaran yang inovatif dan variatif yaitu model kooperatif tipe Think Pair Share. Pembelajaran model kooperatif adalah suatu model pembelajaran dimana siswa belajar yang mana bekerja dalam kelompok-kelompok kecil secara kolaboratif dengan struktur kelompok heterogen. Think Pair Share dikembangkan pertama kali oleh Frank Lyman di University of Maryland yang merupakan salah satu tipe dari model pembelajaran kooperatif. Model 
pembelajaran ini merupakan salah satu model pembelajaran inovatif yang membuat kegiatan belajar lebih interaktif sehingga melatih siswa untuk bekerja sama dengan siswa lain. Radhakrishna, Ewing, \& Chikthimmah (2012) menjelaskan Think Pair Share adalah pembelajaran aktif yang sangat bagus, jika diimplementasikan dengan benar akan menghemat waktu guru dalam menjelaskan, membantu siswa untuk lebih banyak berdiskusi dan berpartisipasi serta memberikan penilaian kumulatif terhadap kemajuan siswa. Think Pair Share adalah pembelajaran kooperatif yang mencakup tiga komponen yaitu waktu berpikir, waktu untuk berbagi dengan pasangan, dan waktu untuk berbagi diantara pasangan pada kelompok yang lebih besar (Bamiro, 2015). Komponenkomponen yang dimiliki Think Pair Share memberikan dampak yang lebih luas dari sekadar meningkatkan hasil belajar secara kognitif. Penggunaan pembelajaran ini dapat mengorganisasikan aspek kognitif dan aspek sosial pembelajaran, perkembangan berpikir dan membangun pengetahuan. Dalam pembelajaran tidak hanya mengembangkan aspek pengetahuan, namun juga menumbuhkan aspek sosial dengan melatih siswa untuk berbagi pengetahuan yang mereka dapatkan. Think Pair Share bisa efektif karena mengundang respons dari semua orang yang berada di dalam kelas tersebut (Enggen \& Kauchak, 2012)

Pembelajaran dengan menerapkan model Think Pair Share diimplementasikan melalui beberapa tahapan. Tahapan-tahapan tersebut yaitu siswa duduk secara berpasangan dalam kelompok ketika guru menjelaskan materi pelajaran; guru mengajukan pertanyaan kepada seluruh siswa; siswa diminta untuk memikirkan jawabannya secara individu; siswa diminta untuk mendiskusikan jawaban mereka bersama kelompoknya, siswa diminta untuk membagikan jawaban mereka yang telah disepakati bersama kepada seluruh siswa yang ada di dalam kelas (Slavin, 1995).

Pembelajaran dengan menggunakan model Think Pair Share selain memberikan manfaat dalam hal keaktifan juga melatih siswa untuk berfikir. Think Pair Share merupakan suatu cara yang efektif untuk membuat variasi suasana pola diskusi kelas yang menentang asumsi bahwa semua diskusi dilakukan dalam pengaturan seluruh kelompok dan prosedur yang digunakan dapat memberikan siswa lebih banyak waktu berpikir, merespons dan saling membantu (Arend, 2013). Dengan demikian memungkinkan semua siswa mengembangkan jawaban yang lebih panjang, lebih kompleks, dan jawaban memiliki alasan karena mereka telah merefleksikan dan mendiskusikannya; siswa lebih berani menyampaikan ide atau gagasan karena mereka sudah mendiskusikannya dalam kelompok; dan memungkinkan interaksi antar siswa (Bamiro, 2015). Seperti dijelaskan Arend dan Bamiro, Think Pair Share memberikan kesempatan siswa untuk mengembangkan kemampuan berfikir untuk menemukan solusi mengenai masalah yang sedang dihadapi. Kesempatan yang diberikan kepada siswa untuk memikirkan jawaban secara individu mengharuskan siswa berfikir untuk menemukan solusi. Jika hal ini dilakukan secara terus menerus akan membuat siswa terampil dalam berpikir dan mencari solusi atas sebuah masalah tanpa ketergantungan dengan solusi yang diberikan oleh orang lain.

Karakteristik siswa sekolah dasar khususnya kelas IV yang masih belajar mengembangkan keterampilan sosialnya seperti kerja sama juga dapat menjadi pertimbangan dalam menghadirkan suasana pembelajaran di kelas. Ketika anak-anak memasuki tahun-tahun sekolah dasar, hubungan timbale balik menjadi penting dalam relasi dengan teman-temannya. Selanjutnya para peneliti juga memperkirakan waktu yang digunakan untuk interaksi sosial juga meningkat. Untuk itu, dengan menerapkan model pembelajaran dengan variasi diskusi kelompok seperti Think Pair Share sesuai dengan karakteristik siswa sekolah dasar kelas IV yang sedang mengembangkan interaksi dan sikap kooperatif (Santrock, 2011). 
Penggunaan model kooperatif Think Pair Share bermaksud untuk mendesain pembelajaran dengan kelompok-kelompok kecil yang memungkinkan untuk saling bekerja bersama. Berdasarkan pernyataan di atas dirancang sebuah penelitian untuk meningkatkan kerja sama siswa menggunakan model Think Pair Share di kelas IV SD. Penelitian ini merupakan sebuah studi eksperimental yang bertujuan untuk mengetahui pengaruh variabel Think Pair Share terhadap variabel kerja sama.

\section{Metode}

Penelitian ini menggunakan pendekatan kuantitatif dengan jenis penelitian kuasi eksperimen dan rancangannya yaitu nonequivalent control group design. Kuasi eksperimen dipilih untuk mengetahui sebab akibat yang mungkin terjadi antara variabel bebas (independent) dengan variabel terikat (dependent). Variabel penelitian ini yaitu Think Pair Share sebagai variabel bebas (X) dan kerja sama sebagai variable terikat (Y).

Populasi dalam penelitian ini yaitu siswa kelas IV segugus Amarta Kecamatan Bener Kabupaten Purworejo. Teknik pengambilan sampel yang digunakan yaitu random sampling. Sampel penelitian ini yaitu siswa kelas IV SD N Ngasinan dan siswa SD N Sidomukti Kelas IV SD N Ngasinan digunakan sebagai kelas eksperimen yaitu dengan memberikan perlakukan. Sedangkan kelas IV SD N Sidomukti sebagai kelas kontrol yang mana pada kelas ini tidak diberikan perlakuan.

Pengumpulan data dilakukan dengan menggunakan angket. Angket dalam penelitian ini digunakan sebagai alat untuk mengukur kerja sama siswa. Angket yang digunakan oleh peneliti termasuk ke dalam angket tertutup karena jawaban sudah tersedia dan responden hanya memilih satu jawaban diantara jawaban yang telah disediakan. Angket diberikan pada pre test dan post test. Hal ini untuk mengetahui pengaruh Think Pair Share model terhadap kerjasama siswa. Sebelum melakukan penelitian, dilakukan validitas terhadap instrument terlebih dahulu. Pengujian validitas instrument menggunakan rumus Alpha Cronbach dengan bantuan program SPSS. Kemudian instrumen diuji reliabilitasnya untuk mengukur tingkat kepercayaan instrumen. Pengujian reliabilitas instrumen menggunakan rumus Kolmogorov Smirnov dengan bantuan program SPSS. Setelah instrumen dinyatakan valid dan reliabel, instrumen dapat digunakan untuk mengambil data di lapangan. Analisis data pada penelitian ini terlebih dahulu menguji normalitas dan homogenitas sebagai uji prasyarat. Selanjutnya dilakukan uji hipotesis menggunakan uji independent sample $t$ test dengan bantuan program SPSS.

\section{Hasil dan Pembahasan}

Pengambilan data dilakukan sebelum diberikan perlakuan (pretest) dan setelah diberikan perlakuan (posttest). Data diperoleh dari kedua kelompok yaitu kelompok kontrol dan eksperimen. Setelah dilakukan penelitian diperoleh beberapa hasil yaitu pretest, posttest, dan pengujian hipotesis.

Pretest dilakukan sebelum dilaksanakannya pemberian perlakuan pada kedua kelas. Tujuan pre test adalah untuk melihat kemampuan awal kerja sama siswa. Adapun hasil pre test yaitu sebagai berikut.

Tabel 1. Skor pretest kerja sama siswa

\begin{tabular}{lcc}
\hline Kelompok & $\begin{array}{l}\text { Jumlah } \\
\text { siswa }\end{array}$ & Rata-rata \\
\hline Kontrol & 30 & 58,83 \\
Eksperimen & 26 & 59,96 \\
\hline
\end{tabular}

Sumber: Data hasil penelitian, 2018

Berdasarkan tabel diatas dapat diketahui skor pre test pada kelas kontrol dengan jumlah siswa 30 memiliki nilai rata rata sebesar 58,83 sedangkan pada kelas eksperimen dengan jumlah siswa 26 anak memiliki nilai rata-rata sebesar 59,96.

Posttest dilakukan setelah pemberian perlakuan baik pada kelas eksperimen maupun kontrol. Hal ini dilakukan untuk mengetahui kemampuan kerja sama setelah adanya perlakuan. Adapun hasil post tes pada penelitian ini adalah sebagai berikut.

Tabel 2. Skor posttest kerja sama siswa

\begin{tabular}{lcr}
\hline Kelompok & Jumlah siswa & Rata-rata \\
\hline Kontrol & 30 & 59,73 \\
\hline
\end{tabular}

84 | Jurnal Civics: Media Kajian Kewarganegaraan 


\begin{tabular}{ccr}
\hline Kelompok & Jumlah siswa & Rata-rata \\
\hline Eksperimen & 26 & 70,80 \\
\hline Sumber: Data hasil penelitian, 2018
\end{tabular}

Berdasarkan tabel diatas diketahui skor posttest pada kelas kontrol dengan jumlah siswa 30 memiliki nilai rata-rata sebesar 59,73 sedangkan pada kelas kontrol dengan jumlah siswa 26 anak memiliki nilai rata-rata sebesar 70,80 .

Selanjutnya dilakukan uji prasyarat analisis sebelum dilakukan uji hipotesis. Uji prasyarat analisis berupa uji normalitas dan homogenitas. Uji normalitas dilakukan untuk mengetahui apakah data tersebut terdistribusi normal atau tidak. Hasil uji normalitas menggunakan rumus Kolmogorov Smirnov dengan bantuan SPSS for windows yaitu pada pretest kelas kontrol sebesar 0,336 sedangkan pada kelas eksperimen sebesar 0,362. Posttest pada kelas kontrol sebesar 0,191 sedangkan pada kelas eksperimen sebesar 0,438. Dapat diketahui bahwa semua data penelitian mempunyai nilai signifikansi lebih besar dari 0,05 yang dapat disimpulkan bahwa semua data pada kelompok eksperimen 1 dan kontrol terdistribusi normal.

Uji homogenitas dilakukan untuk mengetahui apakah sebaran data variabell homogen atau tidak. Pengujian homogenitas dilakukan menggunakan uji $\mathrm{F}$ dengan pengambilan keputusan apabila sig $>0,05$ maka sampel dikatakan homogen atau sebaliknya. Hasil uji coba homogenitas nilai signifikansi lebih besar dari 0,05 pada kelompok eksperimen 1 dan kontrol sehingga dapat disimpulkan bahwa kedua kelompok tersebut homogen. Pengujian analisis prasyarat yang meliputi uji normalitas dan uji homogenitas mendapatkan hasil data yang normal dan homogen. Hasil tersebut memenuhi prasyarat untuk dilakukan uji hipotesis.

Uji hipotesis dilakukan untuk menguji hipotesis yang telah ditetapkan. Pengujian hipotesis pada penelitian ini menggunakan uji independent sample t test. Uji t (independent sample t test) dilakukan karena hanya terdapat satu variabel terikat. Pengambilan keputusan
Ha diterima jika nilai sig $<0,05$ dan Ho diterima jika nilai sig $>0,05$. Adapun hipotesis dari penelitian tersebut yaitu sebagai berikut.

Ha: adanya pengaruh secara positif dan signifikan model kooperatif tipe Think Pair Share terhadap kerja sama siswa kelas IV SD.

Ho: tidak ada pengaruh secara positif dan signifikan model kooperatif Think Pair Share terhadap kerja sama siswa kelas IV SD.

Hasil pengujian hipotesis yang diperoleh setelah dilakukan perhitungan menggunakan pengujian independent sample t test dengan bantuan program SPSS for windows yaitu:

Tabel 3. Hasil uji independent sample ttest model kooperatif tipe Think Pair Share terhadap kerja sama siswa

\begin{tabular}{llc}
\hline $\mathbf{T}$ & Df & Sig. (2-tailed) \\
\hline 4,014 & 54 & 0,000 \\
\hline
\end{tabular}

Sumber: Data hasil penelitian, 2018

Hasil uji independent sample $t$ test menunjukkan nilai thitung sebesar 4,014 dan $\mathrm{p}$ sebesar 0,000 lebih kecil dari 0,05. Hal ini menunjukkan signifikasi lebih kecil dari 0,05 atau Ha diterima dan Ho ditolak. Dengan demikian dapat disimpulkan bahwa terdapat pengaruh model pembelajaran kooperatif tipe Think Pair Share terhadap kerja sama siswa kelas IV SD.

Analisis data dari penelitian ini menunjukkan adanya pengaruh model pembelajaran Think Pair Share terhadap kerja sama siswa. Hal tersebut dibuktikan dengan hasil perhitungan independent sample t-test yaitu nilai thitung sebesar 4,014 dan p sebesar 0,000 lebih kecil dari 0,05 atau Ha diterima Ho ditolak. Artinya bahwa terdapat pengaruh yang positif dan signifikan model pembelajaran kooperatif tipe Think Pair Share terhadap kerja sama siswa kelas IV SD di Kecamatan Bener Kabupaten Purworejo.

Think Pair Share merupakan salah satu model pembelajaran kooperatif dengan desain diskusi kelompok. Langkah-langkah Think Pair Share terdiri dari 3 tahapan yaitu 
thinking, pairing, dan sharing (Arend, 2013). Thinking dimana siswa diminta untuk memikirkan permasalahan secara mandiri atau sendiri-sendiri. Pairing merupakan tahapan dimana siswa memiliki kesempatan untuk berdiskusi dengan teman lainnya mengenai penyelesaian permasalahan atau soal yang telah diberikan guru berdasarkan solusi yang telah mereka pikirkan sebelumnya secara sendiri-sendiri sehingga dapat menemukan kesepakatan tentang penyelesaiannya. Pada tahapan ini siswa bukan lagi bekerja secara sendiri namun bersama temannya, hal ini dapat melatih siswa untuk bekerja sama dalam sebuah kelompok. Dan pada tahap terakhir yaitu tahapan sharing siswa berkesempatan untuk mempresentasikan atau membagikan jawaban mereka pada teman lain di kelas.

Tahapan-tahapan dalam Think Pair Share memastikan siswa bekerja secara berkelompok. Model pembelajaran dengan desain kelompok mengharuskan siswa untuk bekerja dengan orang lain. Model pembelajaran Think Pair Share dapat membantu siswa memahami pentingnya mengintegrasikan ide dan bekerja sama. Bekerja bersama dalam kelompok membantu siswa untuk belajar berinteraksi dengan orang lain sehingga seseorang dapat memiliki sikap saling menghargai, tidak membeda-bedakan dan terbuka (Savage \& Armstrong, 1996).

Think Pair Share merupakan teknik tukar pasangan yang memberi kesempatan kepada siswa untuk bekerja sama untuk berdiskusi sehingga dapat meningkatkan interaksi sosial dan memecahkan masalah keseharian siswa (Kwok \& Lau, 2015; Lee, 2008). Artinya model ini merupakan suatu cara yang efektif untuk membuat variasi suasana pola diskusi kelas yang menentang asumsi bahwa semua diskusi dilakukan dalam pengaturan seluruh kelompok dan prosedur yang digunakan dapat memberikan siswa lebih banyak waktu berpikir, merespons dan saling membantu (Arend, 2013). Jika hal ini dilakukan secara terus menerus akan membuat siswa terampil dalam berpikir dan mencari solusi atas sebuah masalah tanpa ketergantungan dengan solusi yang diberikan oleh orang lain.
Pembelajaran menggunakan desain berkelompok seperti Think Pair Share memudahkan siswa untuk meningkatkan kemampuan akademik maupun sosialnya. Kemampuan akademik ditingkatkan dengan saling memberikan bantuan berupa memberikan penjelasan ketika ada yang kurang memahami materi dan secara sosial akan meningkatkan sikap bekerja sama dengan orang lain. Sebagai makhluk sosial, setiap individu perlu memiliki sikap kerjasama. Kerjasama merupakan kebutuhan penting bagi kelangsungan hidup bagi individu, keluarga, organisasi atau sekolah.

Perkembangan yang terjadi semakin pesat perubahannya menuntut untuk memiliki kemampuan bekerja sama dengan baik. Segala yang dilakukan berhubungan dengan orang lain membutuhkan keterampilan sosial tak terkecuali kerja sama. Tidak hanya dalam dunia nyata, teknologi yang berkembang membuat seseorang bekerja melalui dunia maya juga bertumpu pada kerja sama antar pihak yang terkait untuk mencapai kesuksesan. Banyak masalah sosial yang terjadi yang melibatkan kerja sama yang mana kepentingan bersama mengedepankan kepentingan individu dipengaruhi oleh kepercayaan terhadap anggota lain dalam kelompok (Gächter et al., 2010). Siswa yang memiliki kepercayaan terhadap anggota kelompok lain akan menerima pendapat yang disampaikan oleh teman dan juga akan memberikan tugas pada masing-masing anggota kelompok dengan adil (Frykedal \& Chiriac, 2018; Gächter et al., 2010).

Dapat kita ketahui bersama bahwa faktorfaktor yang mempengaruhi kerja sama antara lain saling percaya antar anggota kelompok dam adanya diskusi kelompok yang mendorong siswa untuk berinteraksi. Faktorfaktor tersebut dapat dikembangkan dengan menerapkan model pembelajaran Think Pair Share. Model tersebut menekankan pada pola diskusi kelompok. Pernyataan tersebut sangat sesuai dengan model pembelajaran Think Pair Share yang memberikan ruang untuk belajar dengan berdiskusi dalam kelompoknya dan member

Berdasarkan hasil analisis data dan penjelasan di atas bahwasannya model 
pembelajaran kooperatif tipe Think Pair Share dapat diimlementasikan ke dalam pembelajaran yang menggunakan pendekatan kurikulum K-13. Hal tersebut dikarenakan pada kurikulum ini siswa dituntut tidak hanya menerima penjelasan dari guru namun siswa juga aktif menggali pengetahuan sendiri dari berbagai hal baik dengan belajar secara sendiri maupun belajar secara kelompok. Senada dengan konsep model pembelajaran Think Pair Share di mana membuat siswa aktif, siswa memikirkan penyelesaian masalah sendiri sebelum berdiskusi dengan pasangannya dan kemudian dibagikan kepada teman sekelasnya. Model pembelajaran Think Pair Share yang didesain dengan memberikan kesempatan siswa untuk bekerja secara individu dan bekerja dengan orang lain yang dapat membuat siswa lebih aktif dan mampu bekerja secara bersama-sama dalam kelompok. Oleh karena itu jika model pembelajaran Think Pair Share diterapkan dengan langkah-langkah yang sesuai dalam pembelajaran yang menggunakan pendekatan kurikulum K-13 tujuan pembelajaran akan tercapai dengan maksimal, sehingga pembelajaran dapat dikatakan berhasil.

Penelitian yang dilakukan hanya menggunakan sampel kecil yaitu satu sekolah sebagai kontrol dan satu sekolah sebagai kelompok eksperimen. Apabila penelitian selanjutnya dilakukan pada sampel yang lebih luas misalnya satu kecamatan maka akan lebih akurat untuk digeneralisasi Penggunaan model pembelajaran yang bertujuan meningkatkan aspek kognitif, afektif, maupun psikomotor siswa sebaiknya terlebih dahulu memperhatikan karakteristik siswa. Model yang tidak sesuai dengan karakteristik siswa tidak akan mendapat hasil yang maksimal. Selain itu, penggunaan model pembelajaran juga perlu memperhatikan materi yang akan diajarkan.

\section{Simpulan}

Pembelajaran dengan model kooperatif tipe Think Pair Share dengan pembelajaran konvensional memberikan dampak yang berbeda pada kemampuan kerja sama siswa. Hal tersebut terbukti dari hasil yang diperoleh pada kelas eksperimen dan kelas kontrol, kerja sama siswa pada kelas eksperimen lebih tinggi dibandingkan dengan kelas kontrol. Sehingga dapat dikatakan bahwa kerja sama pada kelas eksperimen lebih baik dibandingkan dengan kelas kontrol. Dengan demikian dapat diketahui bahwa model kooperatif tipe Think Pair Share berpengaruh terhadap kerja sama siswa.

\section{Referensi}

Altun, S. (2015). The effect of cooperative learning on students' achievement and views on the science and technology course. International Electronic Journal of Elementary Education, 7(3), 451-468.

Arend, R. . (2013). Learning to teach. (M. F. Yulia, Penerj.) (9 ed.). Jakarta: Salemba Humanika.

Bamiro, A. O. (2015). Effects of guided discovery and think-pair-share strategies on secondary school students' achievement in chemistry. SAGE Open, 5(1).

https://doi.org/10.1177/2158244014564 754

Bertucci, A., Johnson, D. W., Johnson, R. T., \& Conte, S. (2016). Effect of task and goal interdependence on achievement, cooperation, and support among elementary school students. International Journal of Educational Research, 79, 97-105. https://doi.org/10.1016/j.ijer.2016.06.01 1

Brinkerhoff, D. B., Ortega, S. T., \& Weitz, R. (2013). Essentials of sociology. Cengage Learning.

Enggen, P., \& Kauchak, D. (2012). Strategi dan model pembelajaran mengajarkan konten dan keterampilan berpikir. (S. Wahono, Penerj.). Jakarta: Indeks.

Frykedal, K. F., \& Chiriac, E. H. (2018). Student collaboration in group work: Inclusion as participation. International Journal of Disability, Development and Education, $1-16$. https://doi.org/10.1080/1034912X.2017. 1363381 
Gächter, S., Herrmann, B., \& Thöni, C. (2010). Culture and cooperation. Philosophical Transactions of the Royal Society B: Biological Sciences, 365(1553), 2651-2661. https://doi.org/10.1098/rstb.2010.0135

Kwok, A. P., \& Lau, A. (2015). An exploratory study on using the thinkpair-share cooperative learning strategy. Journal of Mathematical Sciences, 2, 22-28.

Lee, A. (2008). Cooperative learning: Mempraktikkan cooperative learning di ruang-ruang kelas (6 ed.). Jakarta: Grasindo.

Lickona, T. (2009). Educating for character: How our schools can teach respect and responsibility. New York: Bantam Books.

Muijs, D., \& Reynolds, D. (2008). Effective teaching: Teori dan aplikasi. (H. $\mathrm{P}$. Soetjipto \& S. M. Soecipto, Penerj.) (2 ed.). Yogyakarta: Pustaka Pelajar.

Radhakrishna, R., Ewing, J., \& Chikthimmah, N. (2012). TPS (think, pair and share) as an active learning strategy. NACTA Journal, 56(3), 84.

Santrock, J. W. (2011). Life-span development. New York: The McGrawHill Companies, Inc.

Savage, T. V, \& Armstrong, D. G. (1996). Effective teaching in elementary social studies. (3 ed.). New Jersey: Practice Hall.

Slavin, R. (1995). Cooperative learning: Theory, research, and practice. Boston: Allyn and Bacon. 